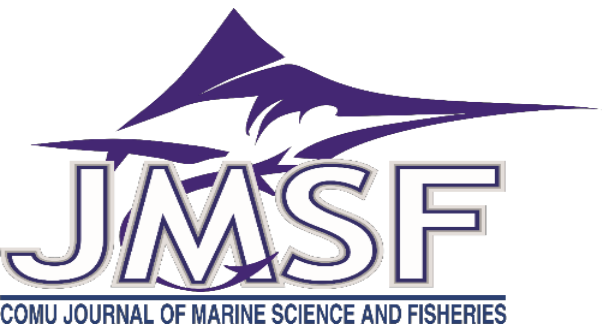

\title{
The Growth and Survival of The European lobster (Hommarus gammarus) Larvae in Pseudo-Green Water and Clear Water under Low Density Conditions
}

\author{
Umur Önal $^{1 *}$, Hakan Baki ${ }^{2}$ \\ ${ }^{1 *}$ Çanakkale Onsekiz Mart University, Faculty of Marine Sciences and Technology, Department of Aquaculture, Terzioğlu Campus, 17100, \\ Çanakkale,Turkey \\ ${ }^{2}$ Çanakkale Onsekiz Mart University, Faculty of Marine Sciences and Technology, Terzioglu Campus, 17100, Çanakkale, Turkey \\ Correspondent: umuronal@yahoo.com \\ Umur Önal: Orcid 0000-0003-3588-8284 \\ Hakan Baki: Orcid 0000-0002-9917-470X
}

How to cite this article: Önal, U., Baki, H. (2021). The growth and survival of the European Lobster (Hommarus gammarus) larvae in pseudo-green water and clear water under low density conditions. COMU J. Mar. Sci. Fish, 4(2): 202-207. DOI: 10.46384/jmsf.1028180

\begin{abstract}
The European lobster, Hommarus gammarus, is a commercially important species in Europe. Despite successful stock enhancement programs during the last two decades, culture methods of $H$. gammarus are still in progress. In this study, the effects of pseudo-green water technique and clear water technique with lower stocking densities on the growth and survival of $H$. gammarus larvae during stages I-IV were investigated. All larvae were reared in $800 \mathrm{~L}$ cylindro-conical tanks with a stocking density of 1.25 larvae/L at a temperature of $17.1 \pm 1{ }^{\circ} \mathrm{C}$ and a salinity of $32 \pm 1$ ppt. Lobster larvae were fed with enriched Artemia at a density of $3-5 \mathrm{naupli} / \mathrm{ml}$ for a period of 10 (09:30 am- 19:30 pm) hours. Daily additions of concentrated algae increased turbidity and reduced visibility in tanks compared to clear water conditions. Results showed that growth of lobster larvae were not significantly different among treatments during planktonic stages I-IV ( $p>0.05)$. Overall mean survival rate was only $3 \%$ with no significant differences between treatments. Increased turbidity and lower stocking density did not improve survival rates. Further studies are required to develop methods that will promote higher survival rates during the pelagic stages of lobster larvae.
\end{abstract}

Key words: Homarid Lobster, Decapoda, Cannibalism, Larval Culture

\section{Avrupa Istakozu (Hommarus gammarus) Larvalarının Düşük Yoğunluk Koşulları Altında Pseudo-Yeşil Su ve Temiz Suda Büyümesi ve Hayatta Kalması}

Özet: Avrupa 1stakozu, Homarus gammarus, Avrupa'da önemli bir ticari türdür. Son yirmi yıldır devam eden başarılı stok geliştirme çalışmalarına karşın, H. gammarus'un yetiştiricilik yöntemleri hala gelişmektedir.Bu çalışmada, düşük yoğunluklu stoklama şartlarında, konsantre alg içeren pseudo-yeşil su ve temiz su tekniklerinin H. gammarus larvalarının I-IV evreler arasındaki büyüme ve hayatta kalma oranları araştırılmıştır. Tüm larvalar $800 \mathrm{~L}$ hacmindeki silindir-konik tanklarda 1.25 larva/L stoklama yoğunluğunda $17.1 \pm 1{ }^{\circ} \mathrm{C}$ sicaklık ve $32 \pm 1 \mathrm{ppt}$ tuzlulukta yetiştirilmiştir. Istakoz larvaları zenginleştirilmiş Artemia ile 3-5 naupli/ml oranında 10 saat süre (09:30 - 19:30) ile beslenmiştir. Tanklara günlük eklenen konsantre alg, eklenmeyen temiz su şartlarına göre türbiditeyi arttırmış ve görüş mesafesini azaltmıştır. Sonuçlar, farklı gruplardaki ıstakoz larvalarının I-IV evrelerde büyüme ve hayatta kalma oranlarının istatistiksel olarak farklı olmadığını göstermiştir ( $\mathrm{p}>0.05$ ). Ortalama hayatta kalma oranı \%3'tü ve gruplar arasında bir farklılık ortaya çıkmamıştır. Artan türbidite şartları ve düşük stoklama yoğunluğu hayatta kalma oranlarını arttırmamıştır. Istakoz larvalarının pelajik evrelerde daha yüksek hayatta kalma oranlarını sağlayacak çalışmaların yapılması gereklidir.

Anahtar kelimeler: Homarid Istakoz, Decapod, Kanibalizm, Larva Yetiştiriciliği 


\section{Introduction}

The European lobster (Hommarus gammarus) is an economically important species throughout Europe ranging from the Mediterranean up to the north-eastern Atlantic Ocean. European lobster production has reached 4700 tonnes as a result of efforts towards increasing natural populations to support fisheries in the last two decades (Casbon, et al., 2021). The hatchery production of the European lobster, particularly in the UK, has become a successful model to support natural populations for this economically important species. In Turkey, since no commercial lobster fleet exists, majority of lobster catches by scuba diving remain unreported and are of a significant concern due to declining populations. Natural harvests dropped from 25 tonnes in 2003 to 1.7 tonnes in 2019 (Anonymus:www.tuik.gov.tr). There is no hatchery production of $H$. gammarus in Turkey and efforts are very limited.

In the hatchery culture, lobster larvae are obtained from egg-bearing female lobsters which are caught from the wild and transferred to hatcheries. Typically, larvae during the first month are cultured communally in cylindro-conical tanks and undergo three planktonic zoea stages (stages I-III) and a post larvae stage IV (Ellis et al., 2015). Larvae are reported to feed with a variety of diets including enriched Artemia naupli, frozen mysid shrimps, mussels and formulated dry diets until they reach stage IV (Nicosia and Lavalli, 1999; Fiore and Tlusty, 2005; Powell et al., 2017). Post larval stage is usually achieved in 16 days at $20^{\circ} \mathrm{C}$, but it may take 9-26 days depending on the temperature (Beard et al., 1985). Typically, survival rates by the beginning of stage IV is $14-20 \%$, but survival rates up to $50 \%$ have been reported (Burton, 2003). Due to cannibalism, lobsters are cultured individually after stage IV and are fed with a variety of diets including raw ingredients and formulated diets.

Despite efforts in the European lobster larviculture during the last 20 years, well-established husbandry protocols with high survival rates during the pelagic phase are not available in detail. Therefore, there is a need to increase survival rates of lobster larvae during the first month of life and develop alternative protocols for mass culture both in terms of simplicity and reproducibility for cost effective rearing of lobsters in captivity. This study investigates the effects of pseudo-green water method and clear water method with lower stocking density on the growth and survival of $H$. gammarus larvae during stages I-IV. Growth of lobsters was also monitored until stage VII and the surviving lobster juveniles were then released to an artificial reef area located off of Dardanos, Çanakkale.

\section{Material and Methods}

In this study, the regulation on the working procedures and principles of the Animal Experiments
Ethics Committee of Turkey was followed. Accordingly, only studies involving experiments on vertebrates and cephalopods require approval by the authorized local Animal Experiments Ethics Committee, Çanakkale Onsekiz Mart University. Studies involving experiments on crustaceans (lobsters) do not require approval. After the experiments, surviving juveniles and the female broodstock were released back into the sea as an experimental stock enhancement initiative.

The experiment was carried out in the Marine Resources Research Laboratory, Faculty of Marine Sciences and Technology, Çanakkale Onsekiz Mart University, located by the Çanakkale Strait (Dardanelles) in Dardanos Campus. Larvae were obtained from a single egg-bearing $H$. gammarus female caught in the Çanakkale Strait. The female lobster was fed ad libitum with the Mediterranean mussels (Mytilus galloprovincialis) until commencement of larval release. The release of larvae covered a period of 10 days with a peak release period between days 5-9. In the experiment, larvae released between days 5-7 were used to minimize potential differences among cohorts.

Larvae were reared in two identical recirculating systems each containing 2 cylindro-conical tanks (total water volume $800 \mathrm{~L} / \mathrm{tank}$ ), a biofilter (total volume 1 ton) and a UV filter (18 watts). Fresh seawater exchange rate was $10 \%$ daily. Overhead illumination with fluorescent lighting provided 100 lux of light at the surface. Aeration was supplied with air stones to prevent larval settlement on the bottom of tanks and water stratification. Water temperature was maintained at $18 \pm 1{ }^{\circ} \mathrm{C}$.

A total of 1000 larvae were added to each tank corresponding to a stocking rate of 1.25 larvae/L. Lobster larvae were reared either in pseudo-green water with concentrated (paste) algae (Nanno 3600, Reed Mariculture, USA) added in culture water (PGW) or in clear water without addition of algae (CW). Duplicate tanks were used for each treatment. Larvae were fed with Artemia nauplii enriched with RotiGrow OneStep (Reed Mariculture, USA) for a period of $24 \mathrm{~h}$ after hatching. Artemia nauplii were maintained at a density of 3-5 individuals/ml during the day and no Artemia was added to the tanks after the lights were turned off.

Once larvae reached stage IV, they were transferred from larval tanks to $4 \times 6 \mathrm{~cm}$ compartments made of plastic mesh. Only larvae that reached stage IV within 5 days were pooled and used for the growout trial. Larvae were randomly allocated to compartments and allowed to acclimate for another 2 days. Larvae were kept separately to prevent cannibalism and fed a diet of fresh mussel and fish meat. Growth was monitored periodically by measuring TL and CL for a period of 40 days. The 
culture system for the larvae culture was also used for the juvenile grow-out trial.

Data were analyzed using the statistical software package IBM SPSS Statistics for Windows (Version 19, IBM, Corp., USA). The suitability of data for ANOVA was checked by Bartlett's test for homogeneity. The growth and survival rates of lobsters were analyzed by ANOVA. Differences in growth and survival among treatments were compared using Tukey's HSD multiple range test $(\mathrm{p}<0.05)$.

\section{Results}

Water quality parameters during the experimental period were as follows: Temperature ranged between $17 \pm 1{ }^{\circ} \mathrm{C}$; salinity was stable and fluctuated between
$32 \pm 1$ ppt, $\mathrm{pH}$ was 8.0-8.2; $\mathrm{NH}_{3}-\mathrm{N}$ levels were always below $0.1 \mathrm{mg} \mathrm{NH} / \mathrm{L}$.

Larval total length (TL) and carapace length (CL) of stage I-III and Stage IV-VII larvae are given in Figures 1 and 2, respectively. Initial mean $( \pm \mathrm{SE}) \mathrm{TL}$ and CL of larvae were $7.679 \pm 0.08$ and $2.712 \pm$ $0.074 \mathrm{~mm}$, respectively. A steady growth was observed in all tanks with no significant differences between treatments. On day 8, the mean TL and CL of stage II larvae were $10.109 \pm 0.117$ and $3.738 \pm$ $0.099 \mathrm{~mm}$, respectively. On day 15 , stage III larvae had a mean TL of $11.166 \pm 0.254$ and a mean CL of $4.080 \pm 0.82 \mathrm{~mm}$. On day 22, the mean TL and CL of stage IV larvae were $13.169 \pm 0.096$ and $5.166 \pm$ $0.046 \mathrm{~mm}$.

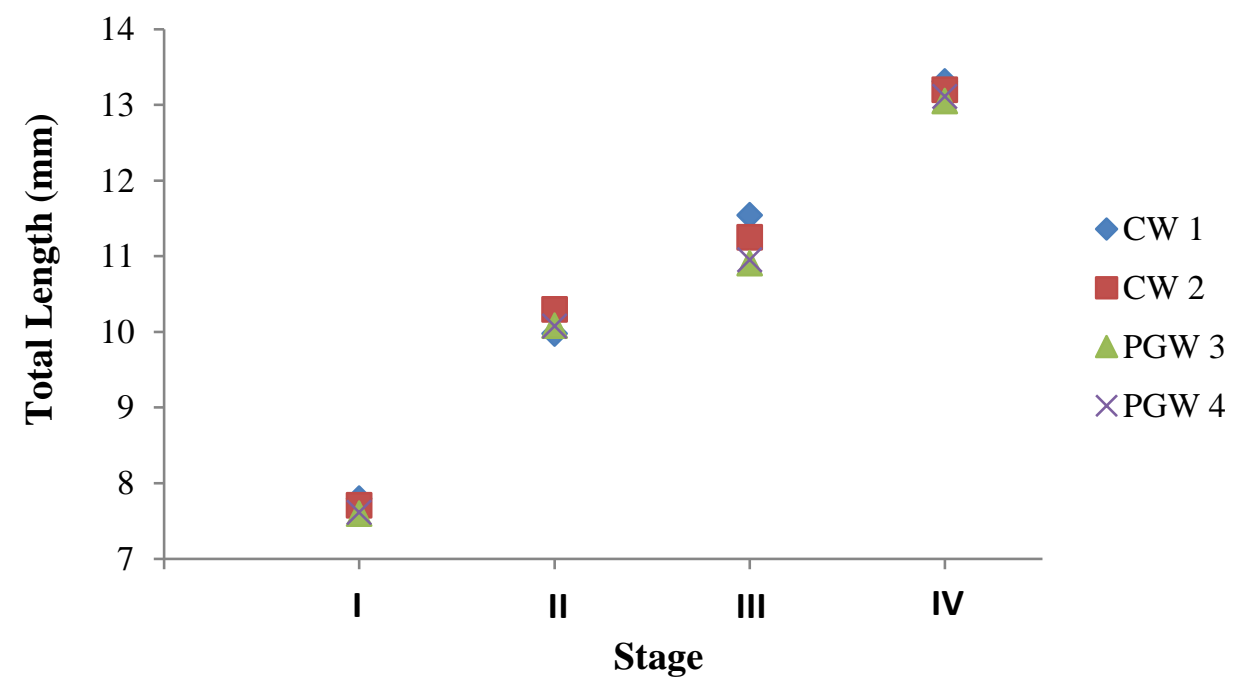

Figure 1. Growth (total length) of lobster larvae reared in clearwater $(\mathrm{CW})$ and pseudo-green water (PGW). Differences were not statistically significant $(\mathrm{p}>0.05)$

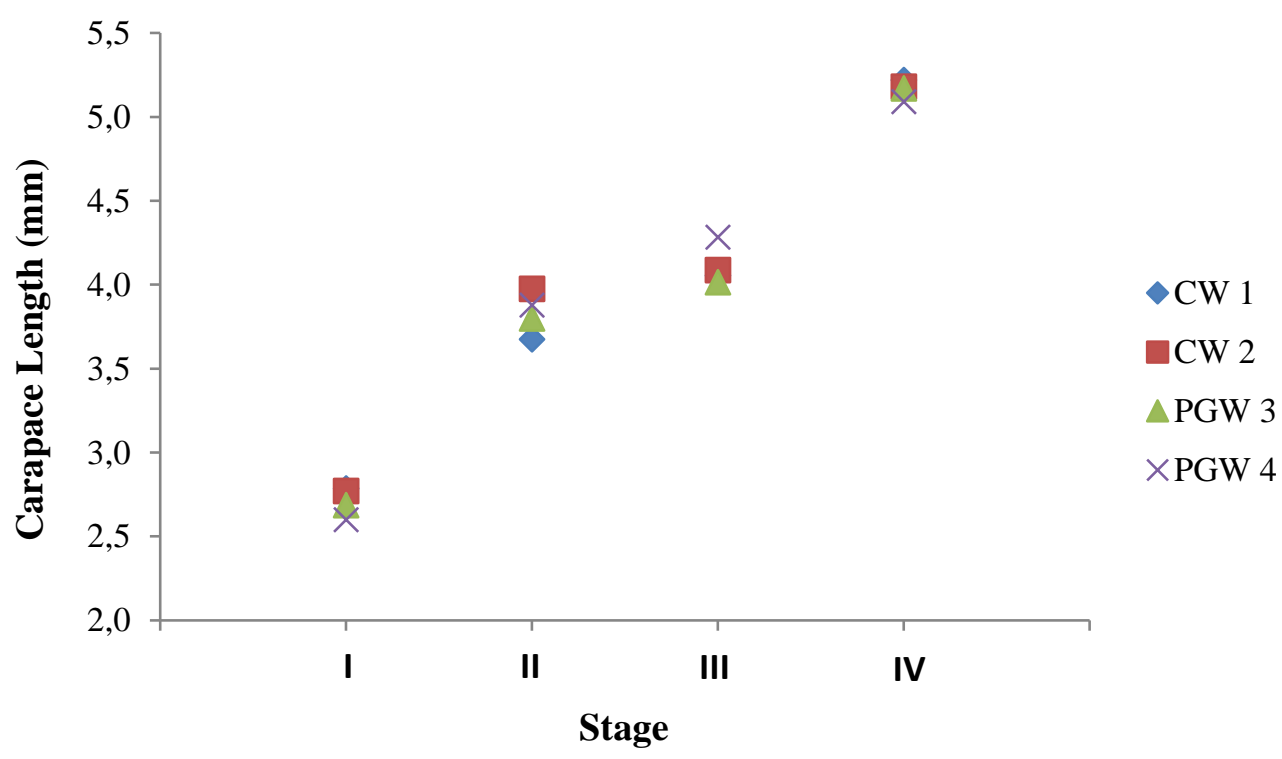

Figure 2. Growth (carapace length) of lobster larvae reared in clearwater (CW) and pseudo-green water (PGW). Differences were not statistically significant $(\mathrm{p}>0.05)$ 
Number of surviving larvae that reached stage IV was 26 in CW1, 34 in CW2, 32 in PGW3 and 29 in PGW 4, with no significant differences between the two treatments $(p>0.05)$. The overall survival rate was $3.1 \%$.

Water quality parameters were identical to those reported for the larval culture experiment. Growth of benthic larvae between stage IV-VII in individual cells was steady. Correlation between TL and CL of juvenile lobsters between stage IV - VII is given in Figure 3. The mean $( \pm \mathrm{SD}) \mathrm{TL}$ and $\mathrm{CL}$ of stage $\mathrm{V}$ larvae were $17.45 \pm 0.43$ and $7.34 \pm 0.32 \mathrm{~mm}$, respectively. Stage VI larvae had a mean TL of 23.07 \pm 1.99 and a mean CL of $9.37 \pm 0.99 \mathrm{~mm}$. The mean TL and CL of stage VII larvae were $29.11 \pm 1.89$ and $11.51 \pm 0.61 \mathrm{~mm}$, respectively. By the end of stage VII, juvenile survival was $80 \%$.

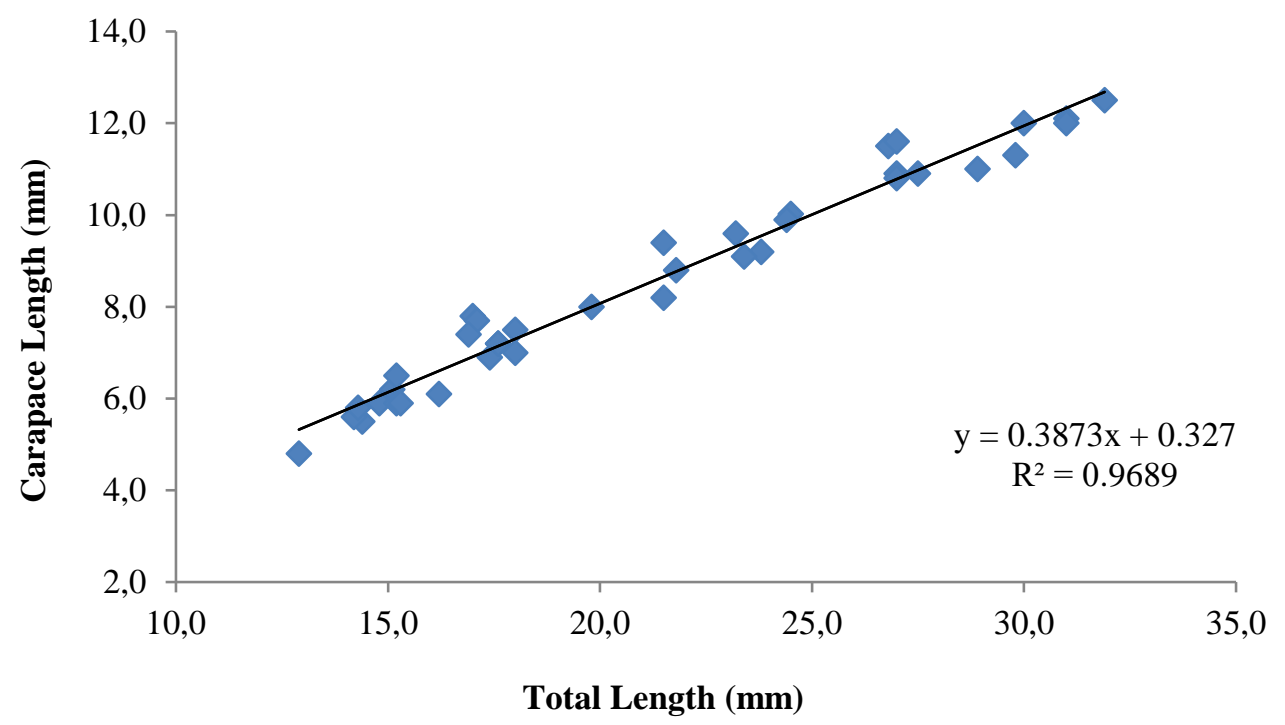

Figure 3. Correlation between total length and carapace length of stage IV-VII larvae

\section{Discussion}

This study showed that growth and survival of $H$. gammarus larvae were similar in clear water and pseudo-green water containing concentrated algae under low density conditions of 1.25 larvae/L. This finding is similar to that reported for $H$. americanus larvae reared in green water consisting live algae (Haché et al., 2017). In contrast, green water technique using either live or concentrated algae is extensively used in the larval culture of many marine organisms like fish and shrimp (Reitan, 1997; Papandroulakis et al., 2001; Skiftesvik et al., 2003). The use of green water has several benefits including increased visibility of prey organisms, increased nutritional content of prey organisms and improved microbial quality of the culture tank and the digestive tract of the target organism. However, green water technique using concentrated algae had limited benefits as the algae cells in concentrated algae were not alive. In addition, turbidity caused by algae cells interfered with routine tank maintenance and observation as the visibility in the tanks was limited to $20-25 \mathrm{~cm}$.

In the present study, a diet of enriched Artemia naupli proved successful for the growth of lobster larvae until stage IV. The growth of larvae during the pelagic stages was similar to those reported in other studies (Agnalt et al., 2013; Middlemiss et al., 2015; Powell et al., 2017). In this study, feeding time was limited to 10 hours (09:30 - 19:30) and no feed was given after lights were turned off. The density of live prey was kept at 3-5 naupli/ml during day time when the lights were on. Larvae were observed to chase the prey and feed on them. In addition, ingested preys were observed in the guts of the larvae under the microscope and indicated active feeding. As expected, prey density in tanks were reduced in the morning and dropped to $<1$ naupli/ml until feeding resumed the next morning. Although no quantitative comparisons were made in terms of gut fullness between day and night time, gut fullness was reduced in early mornings. This may not have been due to reduced feeding activity of lobster larvae during darkness but rather, due to lower amount of Artemia naupli left in the tanks as no feed was provided after the lights were turned off. Lobster larvae are known to be more active during darkness (Powell et al., 2017) and night feeding may improve growth and survival in lobster larvae.

In this study, larval survival rates were lower than those reported in other studies. Typical survival rates of planktonic stages until the beginning of benthic stage (stage IV) are 10-15\% (Jørstad et al., 2009; Ellis et al., 2015). The mean survival rate in this 
study was 3\% with no significant differences among treatments. Survival rates were also similar within treatments. Lower survival rates may be due to a variety of factors such as cannibalism, nutrition and environmental conditions. However, although environmental factors were favorable due to lower stocking density, reduced visibility in PGW tanks or lower stocking rates in both treatments did not improve survival rates. Daily siphoning of tank bottoms were performed as part of routine husbandry, but mortality rates could not be calculated due to cannibalism on conspesifics. On the other hand, lobster larvae in $\mathrm{CW}$ tanks were easily observed due to increased visibility and therefore, allowed better observation opportunity and maintenance of the culture tanks.

Early juvenile growth of lobster larvae showed that growth was steady at a temperature of $17 \pm 1{ }^{\circ} \mathrm{C}$. Mortality was considerably lower compared to pelagic stages when juveniles were kept individually as reported in other studies (Jørstad et al., 2001). These results further confirmed that pelagic stages of lobster larvae remain to be the problematic period in lobster culture.

In the present study, the larvae obtained from a single female lobster, $H$. gammarus, were reared on a diet of enriched Artemia with a mean survival rate of $3 \%$. No significant differences were found in the growth and survival of larvae grown either in clear water or pseudo-green water with concentrated algae. Increased turbidity using concentrated algae and lower stocking density did not promote higher survival rates of lobster larvae. However, the growth of larvae was comparable to those reported earlier in the culture of $H$. gammarus larvae. After the experiments, the surviving lobster juveniles were released to an artificial reef area when they reached stage VIII as an attempt to monitor their growth and survival in the sea. Considering the dramatic decrease in wild lobster populations due to overfishing in Turkey and the recent mucilage phenomenon that will potentially negatively affect benthic life in the Sea of Marmara, there is a need to develop better husbandry protocols for stage I-III larvae in order to start a successful stock enhancement program for lobsters in this region.

\section{Conflict of Interest}

There is no conflict of interest between the authors.

\section{Author Contributions}

Umur Önal planned and designed the study, obtained data on lobster larvae, performed statistical analyses and wrote the manuscript. Hakan Baki was in charge of husbandry and maintenance of lobster broodstock and larval culture.

\section{References}

Agnalt, A.L., Grefsrud E.S., Farestveit E., Larsen M., Keulder F. 2013. Deformities in larvae and juvenile European lobster (Homarus gammarus) exposed to lower $\mathrm{pH}$ at two different temperatures. Biogeosciences, 10: 7883-7895,

Anonymus, Turkish Statistical Institute TÜİK (https://biruni.tuik.gov.tr/medas/?kn=97\& locale $=$ tr) accessed 11.16.2021)

Beard, T. W., P. R. Richards, and J. F. Wickins.1985. The techniques and practicability of year-round production of lobsters, Homarus gammarus, in laboratory recirculation systems. Minist. Agric., Fish., Food, Directorate Fish. Res., Lowestoft, Engl., Fish. Res. Tech. Rep. 79:1-22.

Burton, C.A. (2003) Lobster hatcheries and stocking programmes: an introductory manual. Sea Fish Industry Authority Aquaculture Development Service. Seafish Report, SR552.

Daniel Casbon, D., Wan, A. H.L., Davies, S.J., Hartnett, F. 2021. The European lobster: Using farmed produce to improve wild stocks. International Aquafeed, August 2021: 52-55.

Ellis, C. D., Hodgson, D. J., Daniels, C. L., Boothroyd, D. P., Bannister, R. C. A., \& Griffiths, A. G. F. (2015). European lobster stocking requires comprehensive impact assessment to determine fishery benefits. ICES Journal of Marine Science, 72, 35-48.

Haché, R., Dumas, A., Thumbi, D., Forward., B.S., Mallet, M. 2017. Effect of live algae used as green water on survival, growth, behaviour, ontogeny and bacterial profileof lobster larvae (Homarus americanus Milne Edwards). Aquaculture Research, 48: 581-593.

Jørstad, K. E., Agnalt, A-L.,Kristiansen, T. S., Nøstvold, E. 2001. High survival and growth of European lobster juveniles (Homarus gammarus) reared communally on a natural-bottom substrate. Marine and Freshwater Research, 52: 1431-8

Jørstad, K. E., Kristiansen, T. S., Farestveit, E., Agnalt, A-L., Prodöhl, P. A., Hughes, M., \& Ferguson, A. 2009. Survival of laboratory-reared juvenile European lobster (Homarus gammarus) from three brood sources in southwestern Norway. New Zealand Journal of Marine and Freshwater Research, 43(1): 59-68.

Middlemiss, K.L., Daniels, C.L., Urbina, M.A., Wilson, R. W. Combined effects of UV irradiation, ozonation, and the probiotic Bacillus spp. on growth, survival, and general fitness in European lobster (Homarus gammarus). Aquaculture 444: 99-107.

Nicosia, F., and Lavalli, K. 1999. Homarid Lobster Hatcheries: Their History and Role in Research 
and Aquaculture. Marine Fisheries Reviews, 61 (2): 1-57.

Papandroulakis, N., Divanach, P., Anastasiadis, P., Kentouri, M. 2001. The pseudo-green water technique for intensive rearing of sea bream (Sparus aurata) larvae. Aquaculture International 9: 205-216,

Powell, A., Hinchcliffe, J., Sundell, K., Carlsson, N., Eriksson, S.P., 2017. Comparative survival and growth performance of European lobster larvae, Homarus gammarus, reared on dry feed and conspecifics. Aquaculture Research, 1-11.
Reitan, K.I., Jose R. Rainuzzo, J.R., Gunvor Øie, G., Olsen, Y. 1997. A review of the nutritional effects of algae in marine fish larvae. Aquaculture 155 (1997) 207-221.

Skiftesvik, A.B., Browman, H.I., St-Pierre, J-F. 2003. Life in green water: the effect of microalgae on the behaviour of Atlantic cod (Gadus morhua) larvae. In: The Big Fish Bang. Proceedings of the 26th Annual Larval Fish Conference. Edited by Howard I. Browman and Anne Berit Skiftesvik, Institute of Marine Research, Bergen, Norway. 